\title{
Online Learning Problems in the Covid-19 Pandemic for English Education Students
}

\section{Sholihatul Hamidah Daulay ${ }^{1}$, Nurika Khalila Daulay², Abdul Halim Daulay, Reflina4, Siti Maysarah5, Dita Khairunnisa $^{6}$}

DOI: $10.35445 /$ alishlah.v13i3.779

\section{Article Info}

Keywords:

Students' Problems;

Covid-19;

Online Learning

Kata kunci:

Permasalahan

mahasiswa;

Covid-19;

Pembelajaran Daring

\begin{abstract}
During the Covid-19 pandemic, the teaching and learning process through an online system is one option that can directly deal with barriers to the teaching and learning process to avoid the spread of the virus. This study intends to analyze students responses to the problems they face during the Covid-19 pandemic and how students deal with online learning. The background of this research is students' experience with the problems they face during distance learning or online due to Covid-19, which requires students to follow government rules, namely doing distance learning or online. The informants or respondents in this study were several students majoring in. The data collected by the researchers were based on online interviews conducted with 15 students. The data analysis used the interactive analysis technique by Miles \& Hubberman. The researchers arranged several questions that the participants must ask to obtain the required information. In the online teaching and learning process during the covid-19 pandemic, various problems experienced by students are as follows, the most dominant problem when carrying out online learning is the limited internet network, especially for students who live in rural areas.
\end{abstract}

\begin{abstract}
Abstrak
Selama pandemi Covid 19, proses pembelajaran dan pengajaran dilaksanakan melalui sistem dalam jaringan (daring) adalah merupakan satu pilihan yang tepat dan dapat digunakan untuk mengatasi permasalahan pada proses belajar mengajar itu sendiri serta menghindari penyebaran virus. Penelitian ini bertujuan menganalisis respon mahasiswa terhadap masalah yang mereka hadapi selama pandemi ini. Adapun latar belakang dari penelitian ini adalah masalah maupun pengalaman yang mahasiswa hadapi selama masa pandemic Covid 19 ini, dimana mahasiswa harus mematuhi peraturan pemerintah untuk melaksanakan pembelajaran secara daring. Responden penelitian ini adalah mahasiswa dari prodi Tadris Bahasa Inggris, dimana datanya diperoleh melalui wawancara daring kepada 15 orang mahasiswa. Analisis data dilakukan menggunakan teknik analisis interaktif Miles \& Huberman. Peneliti
\end{abstract}

\footnotetext{
${ }_{1}^{1}$ Universitas Islam Negeri Sumatera Utara, Medan, Indonesia Email: sholihatulhamidah@uinsu.ac.id

${ }^{2}$ Universitas Islam Negeri Sumatera Utara, Medan, Indonesia Email: nurikakhalila@uinsu.ac.id

3 Universitas Islam Negeri Sumatera Utara, Medan, Indonesia Email: halim@uinsu.ac.id

4 Universitas Islam Negeri Sumatera Utara, Medan, Indonesia Email: sitimaysarah@uinsu.ac.id

5 Universitas Islam Negeri Sumatera Utara, Medan, Indonesia

Email: reflina@uinsu.ac.id

${ }^{6}$ Universitas Islam Negeri Sumatera Utara, Medan, Indonesia

Email:ditakhairunisa31@gmail.com
} 


\begin{abstract}
menyusun beberapa pertanyaan yang harus dijawab oleh responden untuk menjaring data yang ada. Dari hasil penelitian ini ditemukan masalahmasalah yang dihadapi oleh mahasiswa selama mengikuti pembelajaran daring, ada pula dampak positif yang mereka alami dan bagaimana mereka menyikapi pembelajaran daring selama Covid-19 ini. Pada proses belajar mengajar di masa pandemi banyak masalah yang dialami oleh siswa seperti keterbatasan jaringan internet terutama pada siswa yang tinggal di daerah pedalaman.
\end{abstract}

\title{
INTRODUCTION
}

Coronavirus Disease 2019 (Covid-19) has spread very fast and to almost all countries, so the World Health Organization (WHO) declared this outbreak a global pandemic in March 2020 (BBC, 2020). All life sectors are affected. To break the chain of the spread of Covid-19, several institutions have implemented a new policy, namely working from home so that there are no services at the office. Even if there are services in the office, the number of employees and visiting is limited, and health protocols are strictly implemented. The Covid-19 pandemic has also changed all aspects of human life, including education. The government has implemented learning from home (WFH) policy through the Ministry of Education and Culture, particularly for education units located in the yellow, orange and red zones. In Jakarta, Surabaya, Medan, Bali and Palembang, the teaching and learning process became studied from home because of the condition of the pandemic outbreaks and in the red zone. On the other hand, the yellow zone can learn from school using a tacit health protocol and a learning schedule by shift system.

However, the online learning process system is an innovation in learning media to overcome obstacles during the pandemic's learning and teaching process (Safarati et al. 2020). The direct impact experienced by students is that the use of internet media can lead to paying more internet fees, ineffective dealing with lecturers if there are materials that are difficult for students to understand and throughout the online learning process, one-way communication often occurs. There are still many problems of online learning that need to be discussed again. So it is necessary to try new research to identify online learning cases, especially from students' point of view. One of the causes of students as objects of research is that learning provides learning services for students.

The online learning system is without direct face-to-face meetings between teachers and students. Still, it uses a digital platform or application using the internet, such as Whatsapp, telegram, zoom meeting, google meet, google classroom, quipped school, teacher's room and other applications. Teachers and students do learning together in different places. The terms online and offline learning emerged as a form of learning pattern in the information technology era as it is today. A positive mindset can help apply online learning media to produce quality learning outcomes. Studying at home using online media expects parents as a role model in children's learning assistance, attitude changes are faced. Preparation before providing learning services is one of the determinants factors in the success of learning, especially in online learning that is far away between learner and learner. In learning, this learner must know the principles of learning and how learners learn. Delivery of tools is not an important factor determining the quality of learning, but rather to the design of subjects determines the effectiveness of learning.

The other problems faced by teachers and students in online learning are the sudden change in the learning system (due to the COVID-19 pandemic) from conventional to online learning certainly has an impact on students and teachers to prepare materials and models and learning methods used. It is uncommon for teachers to experience difficulties in mastering IT so that the learning process does not take place optimally. From the student point of view, all of them only take an absence and are not involved in learning actively because it causes a decrease in learning motivation, learning concentration and an impact on learning achievement.

Almost all educational units experience a similar issue. Every school experiences problems when conducting online learning, namely the lack of students' motivation in learning and mastery of IT by teachers, especially senior teachers or teachers accustomed to teaching conventionally when 
faced with online learning. Moreover, parents of students, especially from the lower middle economy, have not been able to meet the facilities and infrastructure in the implementation of online learning such as laptops, smartphones, credit/quota, and other infrastructure facilities that support the implementation of online learning and monthly tuition payments have not been fully fulfilled.

Many researchers discussed related to online learning or distance learning during the Covid19. Based on Rizaldi \& Fatimah research (2020), they found that distance learning is one an effective solution in continuing the learning process during the COVID-19 pandemic, and in increasing the distance learning success, various considerations are needed, such as infrastructure, teacher and student readiness, and expected learning outcomes. On the other hands, teachers must be able to create and provide usefully and not dull learning conditions, one of which is by using various learning models platforms such as Google Forms, Zoom Cloud Meeting, Whatsapp Groups, Jitsi Meet App and more.

The next research was done by Muhdi et al. (2020). Their research used qualitative research using a mixed-method approach with an iterative analysis design, conducted in 35 districts/cities with 1,899 respondents. They used open-closed questionnaires, a study from 15 documentations, and in-depth interviews in their data collection techniques. Data analysis uses quantitativequalitative software Nvivo12+, with Miles and Huberman models. However, the implementation of online learning policy at Early Childhood Education still takes a lot of effort to become more powerful in preventing a decline in learning, and there are five obstacles in applying such as the ability of parents, the ability of teachers, facility constraints, economic capability and pedagogical constraints

Unexpectedly, after implementing online learning, students' grades and performances fell short of their pre-online learning levels. Even absent students who are frequently late or forget to show up for class even though they are aware of the time and date of the lesson are less likely to perform as well academically as students who are present in person and have the same level of activeness or response. This is why the author is looking into the cause and trying to find a solution. Students of English as a second language should look into the Covid-19 pandemic's effects on online learning in particular.

\section{METHODS}

This study used a qualitative approach, and it aimed to analyze students' problems during online learning. By a qualitative approach, researchers try to understand social phenomena from the participants' perspective through involvement in life (Alwasilah, 2003). The main respondents of this study are 15 students of English education in State University of Islamic North Sumatera, divided into five students from the 2017 academic year, five students from the 2018 academic year, and the last five students from the 2019 academic year. On the other hands, the respondents included 9 females and 6 males. The data collection techniques in this study are semi-structured interviews using telephone or WhatsApp applications. The interviews question: 1) What are the advantages of online learning? 2) What's online learning problems? 3) How is the learning process during a pandemic? 4) What's kind of online learning application? 5) How to use that application easily? The data will be analyzed by using the Miles and Huberman analysis model (1994) in 3 procedures such as data reduction, data display and verification of conclusion. It can be seen in figure 1.

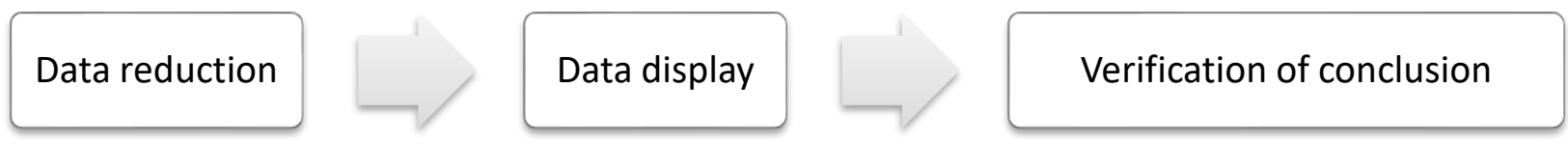

\section{Figure 1. Research analysis procedures}

In data reduction, the researcher collected all information and classified the data. The data display stage contains the data description of the research needed. The last verification which 
concludes the research data and interprets the data to getting a conclusion based on phenomenon. (Miles \& Huberman, 1994)

\section{FINDINGS AND DISCUSSION}

Researchers found responses and opinions after interviewing people, such as KNH (TBI-1), who stated that during the Coronavirus pandemic, we could gather with family to minimize transmission, can gather with old friends to develop hidden soft skills because I like to cook Students become complacent with lessons, lack of supervision during exams, increasing laziness in the human soul, and can never be free of parents with more lectures and a less effective online learning experience. Students are also plagued by the issue of intermittent or unreliable access to the internet. As a final consideration, self-motivation is critical if students are to succeed in distance education.

The next student is SD (TBI-2) declared that by using online learning, we will appreciate more time, be grateful for what you still have, especially health. When you get together with your family, you remember more, later on, it will be difficult to gather with your family. Online learning like this also provides students opportunities to find their special on the sidelines of studying and study on their own they can be more relaxed and not stressed. However, we also lack of interaction with other people, especially with their own friends, so that relationship is difficult to do. The learning materials are less effective, and because of distance learning it is difficult to study with friends. Learning directly is not necessarily possible, let alone learning via online. The next step is to think more about the positive things obtained from this online learning. Because we can't force our predestined will, we can only carry it out by doing positive things.

The other respondent is NH (TBI-2), she said that by learning can be done anywhere. Some lecturers explain the material using voice recordings or video recordings so that they can be watched over and over again. Some courses that require face-to-face explanations are less effective, sometimes signaling is constrained-finally, complete assignments on time without procrastinating. It is similar to the PUY (TBI-2) statement that the online system can learn to manage personal time to be more independent and reduce the spread of covid because many people stay at home with their family. But, the quality of learning can be questioned. Exams cannot be a benchmark for whether students really understand the material presented because there is no control from the teachers/lecturers. Bad and lost connections are also a problem when studying online because she happens to live in a village. Over time, you will adapt to situations like now, force yourself to do productive things to get used to it and become a habit, so staying at home is not a problem to grow.

The last respondent, AK (TBI-2) stated that she has a lot of family time and can develop herself even more. There are many teaching and learning activities that adapt to current conditions, such as videos so that they are easier to repeat. But, lack of direct interaction with people and no direct control by the teacher with students or students. Learn to adapt to circumstances and develop soft skills, especially interacting with other people virtually.

From the results of interviews that researchers have conducted with informants or respondents, and we can conclude that the advantage of online learning during the Covid-19 pandemic is that we can have a lot of time to gather with family at home without going out because it can create a crowd. So, frequent gatherings with family at home can strengthen family relationships. In addition, the advantage of online learning during the next covid-19 pandemic is that it can develop soft skills and make hobbies into productive activities. For example, a student whose hobby is cooking can try new menus from the internet to cook at home. So if we have soft skills that we ourselves don't have time to do because we're busy.

Some parents of students do not have mobile phones that have internet or computers to support online learning, especially for the students themselves. This condition makes them confused with reality. Some students have difficulty accessing the internet network because they live in rural areas and far from cities where internet networks are available. Even if someone uses the internet network, sometimes the network likes to disappear by itself because the area they live in is far from 
the city. The situation that has arisen due to the Covid-19 pandemic requires lecturers to use all available media to support online learning.

In addition to the advantages, online learning during the covid-19 pandemic certainly has weaknesses that make it a problem for students during the covid-19 pandemic. According to the sources we interviewed, the most dominant problem when carrying out online learning is the limited internet network, especially for students who live in rural areas. Some students are even willing to go to a place with a fast internet network, such as near a tree or a relative's house, to follow the lessons given by the lecturer. Furthermore, many students do not understand the explanation given by the lecturer during teaching and learning activities. This can happen because some of the lessons taught in certain courses must be explained directly face face. And the last problem is the lack of interaction and socializing with other people. As the government's recommendation, we are prohibited from staying at home and not going out unless it is essential. Of course, this can make us passive people in interacting.

Based on the review with the students, the researchers get some information about the application used in the learning process, it can be seen in table 1.

Table 1. Online learning application using

\begin{tabular}{cccc}
\hline No & Application & Frequency & Percent \\
\hline 1 & WhatsApp & 4 & 26.67 \\
2 & Zoom & 7 & 46.67 \\
3 & Google Classroom & 4 & 26.67 \\
\hline
\end{tabular}

On the other hand, the student factors it was found that the problems or obstacles experienced by English education students during online learning were:

1. Considering that the implementation of online learning has been going on for almost 1 year since mid-March 2020, some students say it takes too long to make them lazy and bored. Every day, the average students get 2 to 3 subjects for 60 minutes. Usually, each subject provides independent assignments and group assignments to students. Students are also provided with textbooks from schools as materials and references in learning. Online learning situations make students less understanding of the material, causing a feeling of laziness and boredom.

2. A number of students live in areas that do not have internet access, such as in remote villages and geographically located areas that do not allow for a stable internet network. These students are back to their hometowns because their parents lost their jobs in their original residence due to the Covid-19 pandemic. This condition makes them unable to accept the subject matter and even the assignments delivered by the teacher directly maximum. It didn't stop there. Students from underprivileged families were constrained in terms of procuring credit/internet packages/quotas to take part in online learning.

3. Students do not understand the learning material delivered by the teacher. This is because several factors, including the ability of students to participate in online learning, is not comprehensive and depends on physical and psychological conditions when online learning takes place. When students are not fit, it certainly affects concentration and ultimately cannot understand the material given. And when students are in a state of anxiety, anxiety, upset, and other emotions, of course, it makes it difficult to accept learning materials.

Based on the explanation above, it can be seen in table 2.

Table 2. Student's Perception about Online Learning Problems 


\begin{tabular}{cccc}
\hline No & Problems & Frequency & Percent \\
\hline & & & \\
2 & Bored and lazy & 3 & 20 \\
3 & Low internet access & 5 & 33.33 \\
& Do not understand & 7 & 46.67 \\
\hline
\end{tabular}

In line with the findings of this study, Rizaldi and Fatimah (2020) stated that in the implementation of distance learning, all teachers will use several digital applications or platforms such as Zoom Cloud Meeting, Google Classroom, Jitsi meet App, E-learning Kemenag, and other media that can support the learning-teaching process system during the current COVID-19 pandemic. However, they feel more at ease utilizing a WhatsApp group to facilitate communication during the learning process. According to Gunawan et al. (2020), when it comes to the diversity of platforms or applications utilized in the distant learning process, four applications are often used at the University of Mataram, namely Google Classroom, Whatsapp, email, and Zoom cloud meeting.

\section{CONCLUSION}

There are numerous advantages to online learning, including the ability to learn at one's own pace and improve one's memory capacity. Students can also send their assignments via email to lecturers and post comments on discussion forums such as e-learning to enhance their learning experience. Among the many difficulties students encountered while completing their coursework online during the covid-19 pandemic, the most prevalent was the lack of an adequate internet connection, especially for those students who lived in rural areas. It's not uncommon for students who want to stay connected to the lecturer to travel to places with fast internet connections, such as a tree or a family member's house. Students may not understand the lecturer's explanations during teaching and learning activities because some material in the course must be explained face-to-face in order for students to comprehend it. Lastly, the researcher hoped that this study would lead to a new discussion, such as how to deal with the many students' issues during pandemic 19.

\section{REFERENCES}

Agusmanto, Hutauruk., Ropinus, Sidabutar. 2019. Kendala Pembelajaran Daring Selama Masa Pandemi di Kalangan Mahasiswa Pendidikan Matematika: Kajian Kualiatatif Deskriptif. SEPREN: Journal of Mathematics Education and Applied, Vol. 02, No.01

Andri, Anugrahana. 2020. Hambatan, Solusi dan Harapan: Pembelajaran Daring Selama Masa Pandemi Covid-19 Oleh Guru Sekolah Dasar. PGSD Universitas Sanata Dharma.

Asmuni. 2020. Problematika Pembelajaran Daring di Masa Pandemi Covid-19 dan Solusi Pemecahannya. Jurnal Paedagogy: Jurnal Penelitian dan Pengembangan Pendidikan, Vol. 7 No. 4.

Rizaldi, R.D., Fatimah Z. 2020. How the Distance Learning can be a Solution during the Covid-19 Pandemic. International Journal of Asian Education (IJAE). Vol. 01, No. 3, December 2020

Dewi, W. A. F. 2020. Dampak Covid-19 terhadap Implementasi Pembelajaran Daring di Sekolah Dasar. Edukatif: Jurnal Ilmu Pendidikan, Vol 2 No 1.

Gunawan, Suranti, N. M. Y., \& Fathoni. (2020). Variations of Models and Learning Platforms for Prospective Teachers During the COVID-19 Pandemic Period. Indonesian Journal of Teacher Education, 1(2), 61-70.

Herliandry, L., Nurhasanah, Suban, M., Kuswanto, H. 2020. Pembelajaran Pada Masa Pandemi Covid-19. Jurnal Teknologi Pendidikan, Vol. 22. No.1.

Lalu, Gede Muhammad Zainuddin Atsani. 2020. Transformasi Media Pembelajaran Pada Masa Pandemi Covid-19. Al-Hikmah: Jurnal Studi Islam, Vol 1 No 1.

Miles, M. B., \& Huberman, M. (1994). Qualitative Data Analysis Second Edition. SAGE Publications. Morens, D. M., Folkers, G. K., \& Fauci, A. S. 2009. What is a pandemic? The University of Chicago Press. https://doi.org/10.1086/644537 
Muhdi, Nurkolis, \& Yuliejantiningsih, Y. 2020. The Implementation of Online Learning in Early Childhood Education During the Covid-19 Pandemic. JPUD - Jurnal Pendidikan Usia Dini, 14(2), 247-261. https://doi.org/10.21009/JPUD.142.04

Muilenburg, L. Y., \& Berge, Z. L. 2005. Students Barriers to Online Learning: A factor analytic study. In Distance Education (Vol. 26, Issue 1, pp. 29-48). Taylor \& Francis. https://doi.org/10.1080/01587910500081269

Nurhayati, E. 2020. Meningkatkan Keaktifan Siswa Dalam Pembelajaran Daring Melalui Media Game Edukasi Quiz pada Masa Pencegahan Penyebaran Covid-19. Jurnal Paedagogy, Vol 7 No 3 .

Oktafia Ika. 2020. Pembelajaran Daring Sebagai Upaya Study From Home (SFH) Selama Pandemi Covid 19. Jurnal Pendidikan Administrasi Perkantoran (JPAP), 3(8), 496-503. https://doi.org/10.1093/fampra/cmyoo5

Purwanto. 2019. Studi Eksploratif Dampak Pandemi COVID-19 Terhadap Proses Pembelajaran Online. 15(2), 98-112. http://journal.unas.ac.id/oikonamia/article/view/748/620

Risdianto,E., Wachidi, Riyanto, Alexon, Fathurrochman, I., Kusen. 2021. Blended Learning Model Based On Massive Open Online Courses (MOOCS) Assisted by Augmented Reality (BMA) Model as The Electronic Learning Media in The Pandemic Covid-19. Al Ishlah Jurnal Pendidikan. Vol.13 (1). doi: https://doi.org/10.35445/alishlah.v13i1.470

Rizaldi, D.R., Fatimah, Z. (2020). How the Distance Learning can be a Solution during the Covid-19 Pandemic. International Journal of Asian Education, 1(3), 117-124.

Rokhani, T. S. 2020. Pengaruh Work From Home (WFH) Terhadap Kinerja Guru SD Negeri Dengkek 01 Pati Selama Masa Pandemi Covid-19. EduPsyCouns: Journal of Education, Psychology and Counseling, 2(1), 424-437. https://ummaspul.ejournal.id/Edupsycouns/article/view/500

Sadikin A., Hamidah, A. 2020. Pembelajaran Daring di Tengah Wabah Covid-19. BIODIK: Jurnal Ilmiah Pendidikan Biologi. Vol. 6. No.2

Sadikin, A., \& Hamidah, A. 2020. Pembelajaran Daring di Tengah Wabah Covid-19. Biodik, 6(2), 109-119. https://doi.org/10.22437/bio.v6i2.9759

Snell, T. L., Simmonds, J. G., \& Klein, L. M. 2020. Exploring the impact of contact with nature in childhood on adult personality. Urban Forestry and Urban Greening, 55(April), 126864. https://doi.org/10.1016/j.ufug.2020.126864

Wardani, A., \& Ayriza, Y. 2020. Analisis Kendala Orang Tua dalam Mendampingi Anak Belajar di Rumah Pada Masa Pandemi Covid-19. Jurnal Obsesi : Jurnal Pendidikan Anak Usia Dini, 5(1), 722. https://doi.org/10.31004/obsesi.v5il.705 
Al- Ishlah: Jurnal Pendidikan, December 2021, 13 (3), Pages 2373-238o

Sholihatul Hamidah Daulay, Nurika Khalila Daulay, Abdul Halim Daulay, Reflina, Siti Maysarah, Dita Khairunnisa

This page is intentionally left blank 